Acta vet. scand. $1969,10,111-117$.

From the State Veterinary Medical Institute, Helsinki, Finland.

\title{
HIGH INCIDENCE OF CHROMOPHOBE PITUITARY ADENOMA-LIKE LESIONS IN AN INBRED SPRAGUE-DAWLEY BREEDING RAT COLONY
}

\author{
By \\ Per Andersson *)
}

Neoplastic lesions are not infrequent in animal pituitaries. The chromophobe adenoma seems to be fairly common. Isolated cases have been observed in several species, baboon (11), horse $(16,19)$, cow (1), Indian buffalo (8), deer (21), dog $(12,14)$, rat $(6,7,15,18,24,25)$, mouse $(10,21)$ as well as parakeet $(20)$. In our laboratory one case of pituitary adenoma was observed in a parakeet in 1965. Usually these are termed "spontaneous" to distinguish them from experimentally induced tumors. It is, however, quite clear that a spontaneous tumor is only one of which we do not at present know the causative agent. Many different strains of rats have been studied extensively. Bullock \& Curtis (3) and Curtis et al. (5) observed a high incidence of these tumors in a large colony of rats. Five strains, Fisher, August, Marshall, Zimmerman and Copenhagen were represented in the material. Wolfe et al. (24) studied Vanderbilt and Wistar strains and found spontaneous chromophobe adenomas in old rats of both sexes, but particularly in females. The average age was close to 600 days. There were observed marked hemorrhages and hyperemia in the anterior pituitary tumors. Saxton (17) and Saxton \& Graham (18) have studied chromophobe adenoma-like lesions of the rat hypophysis in three different strains, Yale, Sherman and Wistar. In old males of Yale strain ( $600-800$ days) the frequency was $60.7 \%$ and in females of the same age $30.2 \%$.

*) The assistance of Terttu Koponen, M.Sci., State Serum Institute, Helsinki is acknowledged. 
Largest tumor weighed $367 \mathrm{mg}$. Multicentric origin was commonly observed. The neoplastic nodules were not encapsulated, but no invasiveness could be detected. The histological picture was typical with cords of irregular groups of cells. These were chromophobic with lipid cytoplasmic vacuoles. The nuclei were fairly large and vesicular in appearance. Chromatinous granules were coarse. Many nucleoli were intensely eosinophilic and large. Only a few mitotic figures were observed.

The Sherman strain had only few cases (three out of 83 males) of these neoplasms. No females (10 exam.) had the lesions. The age distribution was the same as in the Yale strain. In Wistar strain (in all 79 rats) only one case was observed in a 17 months old male (weight of the tumor $191 \mathrm{mg}$ ). Bielschowsky (2) observed basophil adenomata of the rat anterior pituitary lobe. He considered the cause to be chronic iodine deficiency. In a series of 786 animals of the Rochester strain of Wistar rats Crain (4) observed 11 cases of basophil pituitary adenomata. The age was between 18 and 24 months. Nine were seen in females, two in males. Kim et al. (13) studied mammo-somatotropic pituitary and other tumors in a highly inbred line of Wistar rats. Only female rats were kept until natural death. 17-33 months old females had a high incidence $(27.3 \%)$ of these tumors. Also these authors pointed out that the neoplasms were circumscribed, non-capsulated and usually extremely congested. Unlike radiation induced mouse pituitary tumors, Furth \& Clifton (9), these tumor cells did not invade the bone marrow of the sella and adjacent brain. The neoplasms resembled morphologically those induced by estrogen, which caused mammary gland stimulation. Vartiainen \& Heinivaara (23) induced pituitary adenomas with different extreme dietary regimens in young male albino rats of Sprague-Dawley strain. Talanti (22) has observed similar neoplasms in the Long Ewans strain when working on histochemical problems of hypothalamus. This report deals with "spontaneous" cases of chromophobe adenoma-like lesions of the anterior pituitary lobe of old Sprague-Dawley albino rats in a breeding colony.

\section{MATERIAL AND METHODS}

In a breeding colony of Sprague-Dawley rats a number of males started showing symptoms of drowsiness and inappetence. 
No other symptoms were noted. Routine diagnostic necropsy of four decapitated rats revealed that three of the rats had clearly enlarged pituitaries. All sick animals, 16 males and four females, were placed in all-metal cages individually, and the urinary output was measured. Each sick animal had a healthy pair for control. All animals were under the same regime, feeding, watering and care in the same room. After this all tested animals were decapitated and subjected to a thorough patho-anatomical examination. Histological methods included $\mathrm{He}$, van Gieson and chrom staining. Special attention was drawn to the endocrine organs and CNS as well as the parenchymatous organs.

\section{RESULTS}

The colony consisted of 25 males and 75 females. All animals were about one year old (average 340 days) and had shown no signs of disease previously. As pituitary enlargement was observed in three of four males sacrificed for diagnosis, the rest of the animals were subjected to a thorough clinical examination. Sixteen males and four females showed vague symptoms. These animals were tested five consecutive days for changes in urinary output. Males excreted $15.6 \mathrm{ml} /$ day and females $16.8 \mathrm{ml} /$ day. Individual variation was very small. No increased diuresis was noted.

The frequency of chromophobe adenoma-like pituitary lesions was very high in this colony. For the males it was close to $80 \%$ and for the females $5 \%$.

The males seemed to be somewhat dehydrated despite negative findings in urinary output. Except for three cases of purulent labyrinthitis the macroscopical changes were confined to the pituitaries. There was a wide variation between individual cases. The entire pituitary weight varied in females from 11 to $62 \mathrm{mg}$. The live-weight varied from 280 to $310 \mathrm{~g}$. In males the comparative figures were from 23 to $97 \mathrm{mg}$ and live-weight from 410 to 440 g. All rats showing symptoms had variably enlarged, circumscribed, extremely congested pituitaries. The sella was filled and the hypophysis protruded out pressing the adjacent brain tissue but did not invade it. Macroscopically it was impossible to distinguish in which part of the organ the lesions were. The surface was somewhat nodular. 


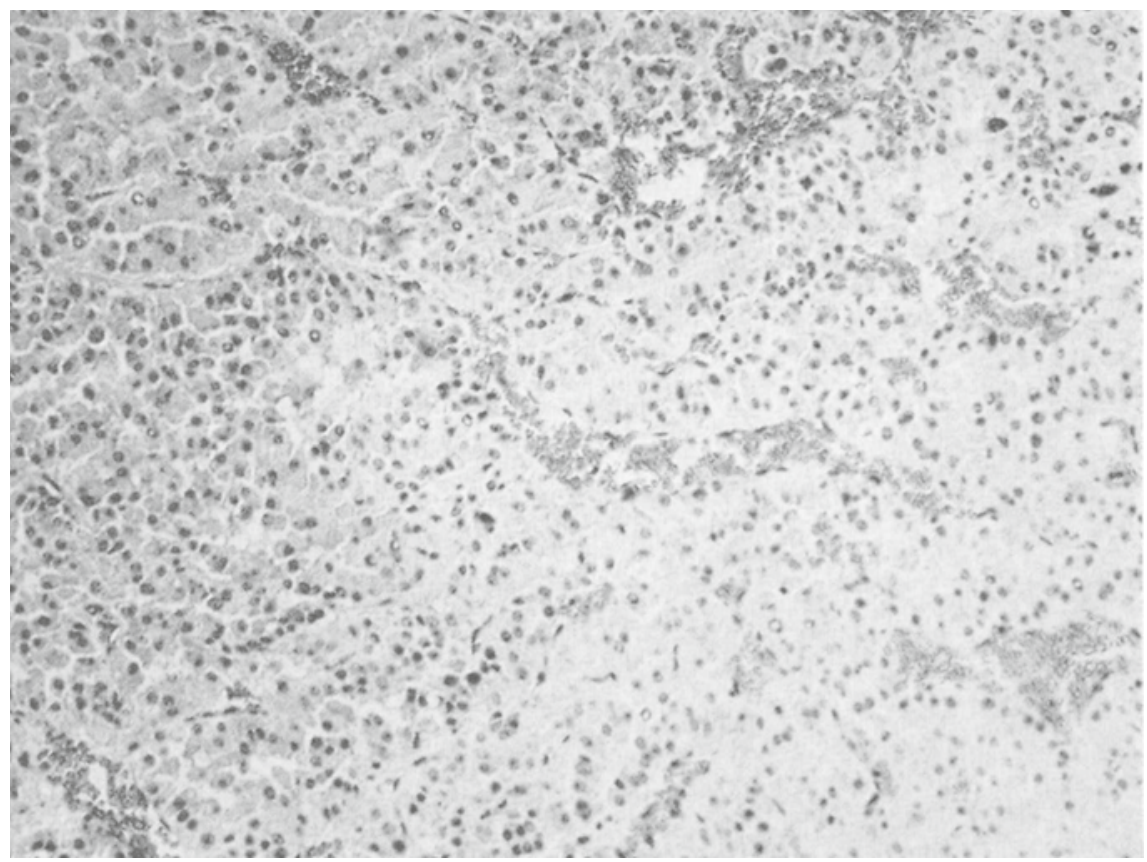

F i g u r e 1. Chromophobe non-capsulated adenoma-like lesion in rat hypophysis. He.

At the histological examination (Fig. 1) no noteworthy changes were found except in pituitaries. The anterior lobe was greatly enlarged with a mass of typical chromophobe cells. They were in cords of irregular groups of varying size. In general the cells were large with numerous lipid vacuoles in the cytoplasm. The nuclei were circumscribed, poor in chromatin which in form of fairly large granules was located mainly to the periphery of the nucleus in a vesicular main mass. Nucleoli were large and strongly eosinophilic indicating increased protein synthesis.

There was no capsule around the usually single neoplastic growth, but signs of invasiveness were lacking. In a few cases more than one small nodule was observed. The vascularity was clearly increased with several often large lacunes of vessels. The tumors had not pressed the adjacent tissue enough as to cause morphological changes in the bones or the nervous tissue. 


\section{DISCUSSION}

Pituitary adenomas seem to be fairly frequent in different lines of inbred laboratory rats. Most reports describe them as chromophobe. Except for extreme experimental conditions no explanation has really been offered for the high prevalence. In this sense the case now described is typical. Fairly young stock animals never subjected to any special known treatment show a large number of pituitary tumors. Some indication might be found in the fact that males in most cases are reported to have a higher incidence. Also the fact that breeding colonies are affected could give a hint of a hormonal background. Also chronic iodine deficiency deserves attention. So far we have no answer to the question of etiology. Naturally animals produced from this stock are not very suitable for experiments. A lesion like pituitary adenoma might seriously affect the results of any experiment.

\section{REFERENCES}

1. Artioli, D.: Adenoma a cellule eosinofile del lobe anteriore dell'ipofise in un bovino. (Acidophil adenoma of the anterior pituitary lobe in a bovine). Riv. Anat. pat. 1949, 1, $298-302$.

2. Bielschowsky, F.: Chronic iodine deficiency as cause of neoplasia in thyroid and pituitary of aged rats. Brit. J. Cancer 1953, 7, 203-213.

3. Bullock, F. D. \& M. R. Curtis: Spontaneous tumors of the rat. J. Cancer Res. 1930, 14, 1-115.

4. Crain, R. C.: Spontaneous tumors in the Rochester strain of the Wistar rat. Amer. J. Path. 1958, 34, 311-335.

5. Curtis, M. R., F. D. Bullock \& W. F. Dunning: A statistical study of the occurrence of spontaneous tumors in a large colony of rats. Amer. J. Cancer 1931, 15, 67-121.

6. Dux, C.: Recherches microscopiques sur les adénomes hypophysaires du rat. (Microscopical investigations of the pituitary adenomas of the rat). Bull. Ass. franç. Cancer 1948, $35,201-216$.

7. Fischer, O.: Über Hypophysengeschwülste der weissen Ratten. (On pituitary tumors of white rats). Virchows Arch. path. Anat. 1926, 259, 9-29.

8. Fox, H.: Pathologic anatomy of the hypophysis cerebri in wild animals. Arch. Neurol. Phychiat. (Chic.) 1927, 17, 471-480.

9. Furth, J. \& K. H. Clifton: Experimental pituitary tumors and the role of pituitary hormones in tumorigenesis of breast and thyroid. Cancer (Philad.) 1957, 10, 842-853. 
10. Gardner, W. U., L. C. Strong \& G. M. Smith: An observation of primary tumors of the pituitary, ovaries, and mammary glands in a mouse. Amer. J. Cancer 1936, 26, 541-547.

11. Goodhart, J. F.: Trans. path. Soc. Lond. 1885, 36, 36. (Cit. Schlumberger (20)).

12. Hare, T.: Chromophobe cell adenoma of the pituitary gland associated with dystrophia adiposo-genitalis in a maiden bitch. Proc. roy. Soc. Med. 1932, 25, 1493-1495.

13. Kim, U., K. H. Clifton \& J. Furth: A highly inbred line of Wistar rats yielding spontaneous mammo-somatotropic pituitary and other tumors. J. nat. Cancer Inst. 1960, 24, 1031-1057.

14. Mulligan, R. M.: Some endocrinologic considerations of canine neoplastic diseases. Arch. Path. 1945, 39, 162-171.

15. Oberling, C. P. \& M. Guerin: Les tumeurs hypophysaires spontanées chez le rat. (Spontaneous pituitary tumors of the rat). Bull. Ass. franç. Cancer 1950, 37, 83-96.

16. Pallaske, G.: Zur Kasuistik seltener Geschwülste bei den Haustieren. (Cases of more uncommon tumors in domestic animals). Krebsforsch. 1932, 36, 342-353.

17. Saxton, J. A.: The relation of age to the occurrence of adenomalike lesions of the rat hypophysis and to their growth after transplantation. Cancer Res. 1941, 1, 277-282.

18. Saxton, J. A., Jr. \& J. B. Graham: Chromophobe adenoma-like lesions of the rat hypophysis. Frequency of the spontaneous lesions and characteristics of growth of homologous intraocular transplants. Cancer Res. 1944, 4, 168-175.

19. Scherer, H. J.: G. Thieme Verlag, Leipzig 1944. (Cit. Schlumberger $(20))$.

20. Schlumberger, H. G.: Neoplasia in the parakeet. I. Spontaneous chromophobe pituitary tumors. Cancer Res. 1954, 14, 237245.

21. Sibley, W. K.: Trans. path. Soc. Lond. 1888, 39, 459-463. (Cit. Schlumberger (20)).

22. Talanti, S.: Personal communication 1968.

23. Vartiainen, I. \& O. Heinivaara: Pituitary tumors induced by different dietary regimens. Ann. Med. intern. Fenn. 1964, 53, $69-73$.

24. Wolfe, J. M., W. R. Bryan \& A. W. Wright: Histologic observations on the anterior pituitaries of old rats with particular reference to the spontaneous appearance of pituitary adenomata. J. Cancer 1938, 34, 352-372.

25. Younghusband, O. Z., G. Horrax, L. M. Hurxthal, H. F. Hare \& J. L. Papper: Chromophobe pituitary tumors. I. Diagnosis. J. clin. Endocr. 1952, 12, 611-630. 


\section{SUMMARY}

A high incidence is recorded of pituitary chromophobe adenomalike lesions in an inbred Sprague-Dawley line of laboratory rats. $80 \%$ of the males and $5 \%$ of the females had the lesion at an age of about 340 days. The patho-anatomical features are described and the significance of the lesion is shortly discussed.

\section{ZUSAMMENFASSUNG}

Hohe Frequenz von chromophobe Adenomen der Hypophyse in einem Inzuchtstamm von weisser Ratten.

Hohe Frequenz von chromophobe Adenomen der Hypophyse in Sprague-Dawley Laboratoriumratten ist beschrieben. Die männlichen Tiere hatten das Leiden in $80 \%$ und die weiblichen in $5 \%$ im Alter von zirka 340 Tagen. Die pathologische Anatomie ist beschrieben und die Bedeutung dieser Tumore kürzlich diskutiert.

\section{SAMMANFATTNING}

Hög frekvens av kromofoba hypofysadenom hos en inavlad stam av vita råttor.

Hos laboratorieråttor av Sprague-Dawley stammen konstaterades kromofoba hypofysadenom hos $80 \%$ av hanarna och $5 \%$ av honorna. Djurens genomsnittliga ålder var 340 dagar. Den patolog-anatomiska bilden beskrivs och tumörernas betydelse diskuteras kort.

(Received October 10, 1968). 